\title{
PENERAPAN MODEL PROBLEM BASED LEARNING UNTUK MENINGKATKAN MOTIVASI DAN PRESTASI BELAJAR EKONOMI SISWA
}

\author{
Titi Suryati
}

SMA Negeri 1 Jalaksana

titisuryati@gmail.com

\begin{abstract}
This study aims to improve the motivation and learning achievement of students XI IPS 4 SMA N 1 Jalaksana school year 2017/2018 through learning Problem Based Learning model. This research is a classroom action research (PTK) conducted in two cycles. Data analysis in this research is based on Descriptive Statistics analysis with Percentage. Technique of collecting data is done by written test, questionnaire, and observation. Motivation of learners is seen by using observation and questionnaire. The results of this study showed an increase in learning motivation of learners from cycle I to cycle II on student motivation questionnaires of 13,39\% in high and very high category. While the increase in learning achievement is marked by the increase of learners whose value reaches the minimum completeness criterion as a whole. In the first cycle of $67,86 \%$ or as many as 19 students achieve the minimum mastery criteria. On the second cycle there is an increase in learners who achieve a minimum mastery of $85,71 \%$ or as many as 24 students. So it can be concluded that the Application of Problem Based Learning Model to Improve Motivation and Achievement of Student Economics Learning Class XI IPS 4 SMA Negeri 1 Jalaksana school year 2019/2020.

Keywords: Problem Based Learning, Learning Motivation, Learning Achievement.
\end{abstract}

\begin{abstract}
ABSTRAK
Penelitian ini bertujuan untuk meningkatkan motivasi dan prestasi belajar peserta didik kelas XI IPS 4 SMA Negeri 1 Jalaksana tahun pelajaran 2019/2020 melalui pembelajaran model Problem Based Learning. Penelitian ini merupakan penelitian tindakan kelas (PTK) yang dilaksanakan dalam dua siklus. Analisis data pada penelitian ini berpedoman pada analisis Statistik Deskriptif dengan Persentase. Teknik pengumpulan data dilakukan dengan tes tertulis, angket, dan observasi. Motivasi peserta didik dilihat dengan menggunakan observasi dan angket. Hasil penelitian ini menunjukan adanya peningkatan motivasi belajar peserta didik dari siklus I ke siklus II pada kuesioner motivasi belajar siswa sebesar 13,39\% pada kategori tinggi dan sangant tinggi. Sedangkan peningkatan prestasi belajar ditandai dengan bertambahnya peserta didik yang nilainya mencapai kriteria ketuntasan minimal secara keseluruhan. Pada siklus I sebesar 67,86\% atau sebanyak 19 siswa mencapai kriteria ketuntasan minimal. Pada siklus II terjadi peningkatan peserta didik yang mencapai nilai ketuntasan minimal sebesar 85,71\% atau sebanyak 24 siswa. Jadi dapat disimpulkan bahwa Penerapan Model Problem Based Learning Untuk Meningkatkan Motivasi Dan Prestasi Belajar Ekonomi Siswa Kelas XI IPS 4 SMA Negeri 1 Jalaksana Tahun Pelajaran 2019/2020 meningkat.

Kata Kunci : Problem Based Learning, Motivasi Belajar, Prestasi Belajar.
\end{abstract}

$$
\begin{array}{l|l|l}
\text { Submitted Apr 15, } 2020 & \text { Revised May 25, } 2020 & \text { Accepted Jun 2, } 2020
\end{array}
$$

\section{Pendahuluan}

Pendidikan sangat diperlukan sebagai upaya untuk mempersiapkan sumber daya manusia (SDM) yang berkualitas, dalam arti menguasai ilmu pengetahuan, mempunyai keterampilan yang dibutuhkan untuk kelangsungan hidup, dan menguasai teknologi untuk mengikuti perkembangan zaman yang nantinya akan berguna untuk kemajuan kehidupan individu itu sendiri maupun kemajuan suatu bangsa. Menurut Undang-Undang nomor 20 
tahun 2003 tentang Sistem Pendidikan Nasional Bab 1, Pasal 1, menyatakan bahwa "Pendidikan adalah usaha sadar dan terencana untuk mewujudkan suasana belajar dan proses pembelajaran agar peserta didik secara aktif mengembangkan potensi dirinya masyarakat, bangsa, dan negara”. Pendidik harus memberikan cara terbaik agar siswa dapat mewujudkan harapan dalam dirinya dan harapan yang diinginkan oleh lingkungan sekitarnya (Lestari, Ansori \& Nahdi, 2019).

Di Indonesia sendiri memanglah banyak hal yang harus dibenahi terkait dengan kualitas pendidikannya. Salah satu masalah pendidikan yang sederhana namun perlu dibenahi adalah cara mengajar guru. Seringkali masih dijumpai cara mengajar yang didominasi oleh guru. Sebagian besar, dalam proses pembelajaran guru masih sangat aktif dan menjadi subjek pembelajaran. Kondisi ini membuat murid tidak leluasa memanfaatkan kemampuan yang dimiliki. Guru harus inovatif menggunakan seni mengajar situasi dengan mengubah gaya mengajar, menggunakan media pembelajaran atau mengubah pola interaksi dengan maksud menciptakan suasana pembelajaran yang menyenangkan (Marno dan Idris, 2010: 141).

Masalah Prestasi belajar juga termasuk masalah yang tak kalah penting. Pada penelitian ini yang dimaksud dengan prestasi belajar adalah hasil perubahan dalam diri siswa yang berupa perubahan tingkah laku sebagai prestasi belajar ekonomi. Pengenalan seseorang terhadap prestasi belajarnya adalah penting, karena dengan mengetahui hasil-hasil yang sudah dicapai maka siswa akan lebih berusaha meningkatkan prestasi belajarnya" (Hamdu \& Agustina, 2011:90). Dengan demikian peningkatan prestasi belajar dapat lebih optimal karena siswa tersebut merasa termotivasi untuk meningkatkan prestasi belajar yang telah diraih sebelumnya. Namun pada realitanya, prestasi belajar ekonomi masih belum memenuhi harapan. Masalah motivasi dan prestasi belajar adalah masalah penting yang harus diperhatikan oleh seorang guru ataupun seorang calon guru karena pendidikan di masa yang akan datang membutuhkan calon guru yang mampu meningkatkan kreatifitas dan keaktifan siswa dalam menemukan materi secara mandiri sehingga siswa menemukan kebermaknaan dalam proses belajar.

SMA Negeri 1 Jalaksana adalah salah satu sekolah yang telah menerapkan kurikulum 2013 revisi dimana kurikulum ini memiliki tujuan mengembangkan potensi siswa secara menyeluruh serta meningkatkan kemauan belajar dari dalam diri siswa sendiri sehingga dengan adanya kemauan dari dalam siswa, diharapkan adanya prestasi maksimal yang diperoleh oleh siswa. Pada kenyataannya pada kelas XI IPS4, kriteria ketuntasan minimal mata pelajaran ekonomi yang diterapkan hanya mencapai 65. Angka 65 ini jika dilihat pada sistem penilaian kurikulum 2013 yang berupa skor huruf, angka 65 hanya memperoleh skor C. Penetapan kriteria ketuntasan minimal oleh guru mata pelajaran ekonomi untuk kelas 11 yang tergolong rendah ini tentunya bukan tanpa alasan, mengingat kemampuan siswa dan hasil belajar siswa yang selama ini dianggap kurang sehingga guru mata pelajaran ekonomi tidak menaikkan angka kriteria ketuntasan minimal. Dengan melihat angka kriteria ketuntasan minimal pada kelas XI maka motivasi dari dalam diri siswa perlu ditingkatkan. Salah satu usaha yang dapat dilakukan guru untuk meningkatkan motivasi belajar siswa adalah pemberian variasi dalam pembelajaran.

Dengan adanya variasi pembelajaran, diharapkan siswa merasa tertarik untuk mempelajari secara mandiri dan berimbas pada prestasi yang ikut meningkat. Hal semacam ini sangat diperlukan di kelas XI mengingat angaka kriteria ketuntasan minimal yang hanya mencapai 65 dengan alasan pencapaian prestasi belajar siswa kelas XI selama ini masih rendah. 
Dari data nilai murni ujian kenaikan kelas semester genap siswa kelas X IPS SMA Negeri 1 Jalaksana, bahwa hasil pencapaian siswa kurang memuaskan. Terbukti dengan nilai rata-rata siswa yang berada di bawah kriteria ketuntasan minimal di setiap kelasnya. Jika dilihat dari kriteria ketuntasan minimal mata pelajaran ekonomi di SMA Negeri 1 Jalaksana, ada hal penting yang harus diperhatikan guru dimana siswa kelas X yang naik kelas XI pada tahun pelajaran 2018/2019 ini, dihadapkan pada angka kriteria ketuntasan minimal yang lebih rendah dari angka kriteria ketuntasan minimal pada saat kelas X. Guru mata pelajaran ekonomi kelas XI harus memperhatikan keadaan ini, karena dengan kriteria ketuntasan minimal yang harus dicapai lebih rendah dari ketika duduk di kelas X, bisa saja siswa kurang memperhatikan angka kriteria ketuntasan minimal ini dan berakibat pada motivasi belajar siswa yang menurun. Jika terjadi penurunan motivasi siswa, maka prestasi yang diperoleh pun tidak maksimal. Penting bagi guru mata pelajaran ekonomi kelas XI untuk menghindari adanya penurunan motivasi siswa,salah satunya dengan mengantisipasinya dengan pemberian variasi model pembelajaran dari guru. Dimana variasi model ini jika diterapkan guru secara tepat akan mempengaruhi motivasi siswa dalam belajar.

Berkaitan dengan kemampuan cara-cara mengajar, wajib bagi seorang guru mengetahui seluruh model-model pembelajaran yang terdapat dalam pelaksanaan suatu pembelajaran yang berkaitan dengan prestasi belajar siswa. Kemampuan guru untuk memilih model pembelajaran yang tepat akan menghasilkan kemauan belajar berasal dari dalam diri siswa yang pada akhirnya akan meningkatkan prestasti siswa. Jika kemauan belum muncul dari dalam diri siswa itu sendiri, maka tugas guru lah yang harus membuat siswa menjadi tertantang ingin mempelajari suatu materi salah satunya dengan model pembelajaran yang tepat.

PBL adalah pemberian masalah yang berhubungan dengan kehidupan seharihari kepada siswa kemudian siswa secara berkelompok mencari alternatif solusi untuk menyelesaikan masalah tersebut. Sedangkan menurut Dutch (dalam Amir 2009:21) Problem Based Learning merupakan metode instruksional yang menantang siswa agar belajar untuk belajar, bekerja sama dalam kelompok untuk mencari solusi bagi masalah yang nyata masalah ini diguakan untuk mengingatkan rasa keingintahuan serta kemampuan analitis dan inisiatif atas materi pelajaran. PBL mempersiapkan siswa untuk berpikir kritis dan analisis dan untuk mencari dan menggunakan sumber pembelajaran yang sesuai. Oleh karena itu diperlukan model pembelajaran yang variatif dan cara untuk memotivasi siswa agar motivasi siswa naik dan siswa menjadi antusias dalam mengikuti pembelajaran ekonomi dan pada akhirnya memperoleh hasil yang maksimal. Beberpa hasil penelitian yang dilakukan oleh Nisak \& Sari (2013), Nurtanto (2016), Suarni (2017), dan Rahmat (2018).

\section{Metode Penelitian}

Penelitian ini termasuk penelitain tindakan Kelas (PTK) yang dilaksanakan sebagai upaya untuk memperbaiki pembelajaran ekonomi dan meningkatkan partisipasi siswa dalam pembelajaran. Menurut Kemmis dan Taggart (Rochiati Wiriaatmaja, 2006 : 66 - 67), Penelitian Tindakan Kelas memiliki empat tahap dalam satu siklus. Tahapan tersebut ialah (1) Plan (Perencaaan), (2) Act (tindakan), (3) Observe (pengamatan), (4) reflect (refleksi).

Jenis penelitian ini adalah penelitian deskriptif. Menurut Suparno (2010:3) penelitian deskriptif bertujuan untuk memberikan penjelasan atau uraian akan suatu hal. Penelitian ini menggunakan dua macam metode penelitian, yakni penelitian kuantitatif dan deskriptif 
kualitatif. Penelitian kuantitatif adalah desain riset yang menggunakan data berupa skor atau angka yang kemudian akan dianalisis dengan statistik (Suparno, 2010:7). Pengumpulan data pada penelitian ini melalui observasi dan kuisioner untuk mengetaui motivasi dalam belajar. Serta data nilai pre test dan post test untuk mengetahui prestasi belajar siswa. Objek dalam penelitian ini adalah motivasi dan prestasi belajar ekonomi peserta didik kelas XI IPS 4 SMA Negeri 1 Jalaksana tahun ajaran 2019/2020 melalui penerapan model Problem Based Learning (PBL)

\section{Hasil dan Pembahasan}

Penelitian ini menerapkan pembelajaran model Problem Based Learning pada mata pelajaran ekonomi. Pembelajaran tersebut dilaksanakan untuk meningkatkan motivasi belajar dan prestasi belajar peserta didik kelas XI IPS 4 di SMA Negeri 1 Jalaksana. Tahapan kegiatan tersebut adalah sebagai berikut :

1. Tes Individual

Sebelum guru menyampaikan materi, peseta didik terlebih dahulu mengerjakan soal pre test secara mandiri. Pre test ini bertujuan untuk mengetahui kemampuan awal peserta didik.

2. Persiapan Pembelajaran

Pada tahap ini, guru mempersiapkan materi yang akan disampaikan dan media yang akan digunakan. Peserta didik dibagi menjadi delapan kelompok, masing- masing kelompok terdiri dari tiga sampai empat peserta didik. Kemudian, peserta didik mendengarkan penjelasan guru.

3. Penyajian Materi

Guru menjelaskan materi dengan menggunakan media video. Peserta didik memperhatikan vidoe yang diputar dan diharapkan dapat saling berdiskusi satu sama lain dengan teman kelompoknya.

4. Kegiatan Belajar Kelompok

Pada tahap ini, peserta didik diminta untuk berdiskusi mengerjakan lembar kerja. Setiap anak harus berkontribusi dalam menyelesaikan soal. Peserta didik diminta untuk mengerjakan dengan maksimal. Guru sesekali berkeliling untuk memastikan semua peserta didik ikut berkontribusi mengerjakan soal.

5. Presentasasi Kelompok

Setelah diskusi dengan kelompok selesai, masing masing kelompok menyiapkan 1 perwakilan guna memaparkan hasil diskusi kelompoknya. Saat ada 1 kelompok yang memaparkan hasil diskunya, maka setelah selesai kelompok lain berhak untuk menyanggah maupun memberikan pertanyaan kepada kelompok tersebut.

6. Penarikan Kesimpulan

Setelah kelompok mempresentasikan hasil diskusi kelompok, guru dan siswa melakukan penarikan kesimpulan dari materi yang dipelajari.

7. Tes Individual

Peserta didik diminta untuk mengerjakan soal post test secara individual. Hal ini bertujuan untuk mengetahui peningkatan prestasi belajar peserta didik setelah dilakukan tindakan berupa pembelajaran dengan model Problem Based Learning.

Penerapan model pembelajaran Problem Based Learning, menunjukkan adanya peningkatan motivasi dan prestasi belajar dari siklus I ke siklus II. Berikut penjelasannya : 
a. Perhitungan Skor Motivasi Belajar Peserta Didik

Berdasarkan pehitungan skor motivasi belajar peserta didik diketahui bahwa skor meningkat pada siklus I ke siklus II. berikut rincian hasil observasi dan angket motivasi peserta didik :

1) Hasil Observasi

Observasi motivasi peserta didik dilakukan peneliti yang dibantu oleh satu orang observer. Observasi dilakukan kepada seluruh peserta didik kelas XI IPS 4 SMA Negeri 1 Jalaksana pada saat pembelajaran berlangsung. Pengamatan dilakukan dua kali pada saat siklus I dan siklus II. Hasil observasi pada siklus I maupun siklus II menghasilkan persentase skor tiap indikator yang diamati. Kemudian persentase tersebut dihitung skor rata-ratanya dan dihitung persentase peningkatan tiap indikator maupun pada skor rataratanya. Sehingga kedua siklus dapat diamati seberapa besar persentase peningkatannya.

Tabel 1. Perbandingan Observasi Motivasi Belajar Siswa Siklus 1 dan Siklus 2

\begin{tabular}{|c|c|c|c|c|}
\hline \multirow{2}{*}{ No } & \multirow{2}{*}{ Indikator Motivasi Belajar } & \multicolumn{2}{|c|}{$\begin{array}{l}\text { Persentase skor } \\
\text { motivasi }\end{array}$} & \multirow{2}{*}{$\begin{array}{l}\text { Persentase } \\
\text { peningkatan }\end{array}$} \\
\hline & & Siklus I & Siklus II & \\
\hline 1 & Ketekunan dalam belajar & 66,96 & 79,46 & 12,50 \\
\hline 2 & Ulet menghadapi kesulitan & 67,86 & 81,25 & 13,39 \\
\hline 3 & $\begin{array}{l}\text { Adanya dorongan dan kebutuhan } \\
\text { dalam belajar }\end{array}$ & 66,96 & 80,36 & 13,40 \\
\hline 4 & $\begin{array}{l}\text { Adanya hasrat keinginan untuk } \\
\text { berhasil }\end{array}$ & 66,96 & 81,25 & 14,29 \\
\hline \multicolumn{2}{|c|}{ Jumlah } & 268,74 & 322,32 & 53,58 \\
\hline \multicolumn{2}{|c|}{ Rata - rata skor Motivasi } & 67,19 & 80,58 & 13,39 \\
\hline
\end{tabular}

Tabel di atas menunjukan bahwa terjadi peningkatan rata-rata skor motivasi pada siklus I ke siklus II. Terlihat bahwa terjadi peningkatan pada semua indikator dari siklus I ke siklus II. Berdasarkan data tersebut peningkatan tertinggi ada pada indikator "adanya hasrat keinginan untuk berhasil”. Hal ini dikarenakan pada saat siklus I peserta didik cenderung bermalas-malasan pada saat mengerjakan tugas, baik kelompok maupun individu. Namun pada saat siklus ke II, peserta didik terlihat lebih bersemangat, karena sebelumnya guru memotivasi peserta didik dan memberi penjelasan tujuan peserta didik mengerjakan tugas baik kelompok maupun mengerjakan soal individu. Sehingga mereka termotivasi.

Sedangkan peningkatan skor terendah ada pada indikator "adanya dorongan dan kebutuhan dalam belajar". Hal ini dikarenakan pada saat pembelajaran, peserta didik masih terlihat enggan bertanya ketika ada hal-hal baru yang disampaikan oleh guru karena budaya bertanya yang tidak dibiasakan.

2) Hasil Angket

Angket dibagikan kepada peserta didik sebanyak dua kali yaitu sebelum dilakukan siklus I dan setelah dilakukan siklus II. Hal ini bertujuan agar motivasi peserta didik dapat dilihat sebelum dilakukan siklus I. Kemudian dapat dilihat pula seberapa peningkatan 
dilakukan siklus II. Keberhasilan tindakan dapat dilihat dari selisih antara persentase skor motivasi pada siklus I dengan siklus II.

Pada hasil angket siklus I, motivasi siswa rata - rata masuk pada kategori tinggi dengan persentase $96,43 \%$, artinya peserta didik sudah memiliki motivasi yang cukup tinggi pada saat dilakukan pembagian angket pada siklus I. Meski demikian, yang diharapkan adalah tingkat motivasi yang sangat tinggi dapat terjadi pada peserta didik, mengingat masih ada 3,57 \% peserta didik yang memiliki motivasi cukup rendah. Pada siklus II, terjadi penginkatan presentase motivasi pada peserta didik. Dalam kategori sangat tinggi mengalami peningkata persentase yang tinggi, naik sebesar 39,27\%. Berdasarkan uraian di atas, dapat dilihat bahwa ada peningkatan motivasi belajar dari siklus I ke siklus II sebasar $14,29 \%$ pada kategori tinggi dan sangat tinggi. Baik indikator yang ada pada lembar observasi maupun angket. Sebagian besar indikator yang digunakan pada keduanya sama. Peningkatan Prestasi Belajar Siswa

Hasil penelitian menunjukkan bahwa penerapan model pembelajaran Problem Based Learning juga meningkatkan prestasi belajar peserta didik. Peningkatan prestasi belajar tersebut dilihat dari adanya peningkatan rata-rata nilai kelas dan peningkatan persentase peserta didik yang memenuhi kriteria ketuntasan minimal (KKM) yang telah ditentukan dari siklus I ke siklus II. Hal ini dapat dilihat dalam tabel di bawah.

Tabel 2. Perbandingan Nilai Pree Test dan Post test Siklus I dan Siklus II.

\begin{tabular}{ccccccccc}
\hline & \multicolumn{4}{c}{ Siklus I } & \multicolumn{4}{c}{ Siklus II } \\
Kategori nilai & \multicolumn{2}{c}{ Pre Test } & \multicolumn{2}{c}{ Post Test } & \multicolumn{2}{c}{ Pre Test } & \multicolumn{2}{c}{ Post Test } \\
& Frek. & $\%$ & Frek. & $\%$ & Frek. & $\%$ & Frek. & $\%$ \\
\hline Nilai $<65$ & 26 & 92,86 & 9 & 32,14 & 18 & 64,26 & 4 & 14,29 \\
Nilai $\geq 65$ & 2 & 7,14 & 19 & 67,86 & 10 & 35,74 & 24 & 85,71 \\
JML & 28 & 100 & 28 & 100 & 28 & 100 & 28 & 100 \\
Rata-rata & 55,43 & \multicolumn{2}{c}{71,07} & 62,96 & 81,71 \\
\hline
\end{tabular}

Tabel di atas menujukan ada peningkatan nilai rata-rata pre test dan post test baik pada siklus I maupun siklus II. Pada siklus I, rata-rata nilai pre test sebesar 55,43 dengan jumlah peserta didik yang tuntas atau memiliki nilai $\geq 65$ sebanyak 2 peserta didik. Namun terjadi peningkatan setelah dilaksanakan pembelajaran dengan teknik Problem Based Learning yaitu nilai rata-rata post test menjadi 71,07 dan yang meraih nilai $\geq 65$ sebanyak 19 peserta didik. Hal tersebut menunjukan terjadi peningkatan meski belum mencapai kriteria ketuntasan yang diharapkan. Begitu pula pada siklus II, nilai rata-rata siswa mengalami peningkatan dari 62,96 dengan jumlah peserta didik yang tuntas atau memiliki nilai $\geq 65$ sebanyak 10 peserta didik, rata-rata nilai menjadi 81,71 dengan jumlah peserta didik yang tuntas atau memiliki nilai $\geq 65$ sebanyak 24 peserta didik.

Pada siklus ke II ini, rata-rata nilai dan jumlah peserta didik yang tuntas KKM sudah memenuhi target yang diharapkan yakni rata-rata nilai mencapai 81,71 dan jumlah peserta didik yang tuntas KKM mencapi 85,71\% dari jumlah peserta didik kelas XI IPS 4. Sehingga dapat dikatan bahwa pembelajaran teknik Problem Based Learning dapat meningkatkan prestasi belajar ekonomi peserta didik kelas XI IPS 4. 


\section{Simpulan}

Berdasarkan hasil analisis data yang telah dilakukan maka dapat diambil kesimpulan sebagai berikut : (1) Pembelajaran dengan menggunakan model Problem Based Learning pada kelas XI IPS 4 SMA Negeri 1 Jalaksana meningkatkan prestasi bejar siswa dilihat dari kenaikan nilai rata - rata pre test dan post test siswa. Rata- rata nilai mencapai 81,71 dan jumlah peseta didik yang tuntas KKM mencapai 24 siswa atau 85,71\% dari jumlah peserta didik kelas XI IPS 4. (2) Pembelajaran dengan menggunakan model Problem Based Learning pada kelas XI IPS 4 SMA Negeri 1 Jalaksana meningkatkan motivasi belajar siswa dilihat dari peningkatan rata - rata skor hasil angket sebesar 14,29\% pada kategori tinggi dan sangat tingi dari siklus I ke Suklus II.

\section{Daftar Pustaka}

Amir, M. (2009). Inovasi Pendidikan melalui Problem Based Learning. Jakarta: Perdana Media Group.

Akbar, S. (2013). Instrumen Perangkat Pembelajaran. Bandung: Remaja Rosdakarya.

Arifin, Z. (1991). Evaluasi Instruksional Prinsip Teknik dan Prosedur. Bandung: RmajaRosdakarya.

Arikunto, S. (2003). Prosedur Penelitian Suatu Praktik. Jakarta: Bina Aksara.

Dalyono. (2005). Psikologi Pendidikan. Jakarta : Rineka Cipta.

Hamdayana, J.. (2014). Model dan Metode Pembelajaran Kreatif. Jakarta: Ghalia Indonesia.

Hamdu dan Agustina. (2011). Pengarub Motivasi Belajar Siswa Terhadap Prestasi. Jakarta: Bina Aksara.

Lestari, F. Y. P., Ansori, Y. Z., \& Nahdi, D. S. (2019). Model Inkuiri Terbimbing Dalam Meningkatkan Keterampilan Berpikir Kritis Ips Siswa SD. Prosiding Seminar Nasional Pendidikan FKIP Universitas Majalengka, 509-516. Retrieved from http:// prosiding.unma.ac.id/index.php/semnasfkip/article/view/73

Mustaji dan Arthana. (2005). Evaluasi Media Pembelajaran. Unesa Univercity Press.

Marno, dan M. Idris. (2010). Strategi dan Metode Pengajaran. Jogjakarta: Ar- ruzz Media Group.

Nisak, C. \& Sari, A.R. (2013). Penerapan Model Problem Based Learning Untuk Meningkatkan Aktivitas Dan Prestasi Belajar Akuntansi. Jurnal Pendidikan Akuntansi, 11(1).

Nurtanto, M. (2016). Peningkatan Motivasi Dan Prestasi Belajar Dengan Metode Problem Based Learning Pada Pembelajaran Gambar Teknik Melalui Pembelajaran Terbimbing. VANOS Journal of Mechanical Engineering Education, 1(2).

Rahmat, E. (2018). Penerapan Model Pembelajaran Problem Based Learning (PBL) untuk Meningkatkan Prestasi Belajar Siswa. Jurnal Penelitian Pendidikan, 18(2), 144-159

Suarni, D.A.K. (2017). Penerapan Model Pembelajaran Problem Based Learning Untuk Meningkatkan Prestasi Belajar IPS. Jurnal Ilmiah Sekolah Dasar, 1(3), 206-214. 